\title{
CONTOH BAHASA PEMROGRAMAN DELPHI
}

\author{
MUHAMMAD DENNY PRAYOGA \\ 165100046 \\ Fakultas Komputer, 448757291 \\ muhammaddenny.student@umitra.ac.id
}

\begin{abstract}
Delphi adalah Suatu bahasa pemrograman yang menggunakan visualisasi sama seperti bahasa pemrograman Visual Basic ( VB ). Namun Delphi menggunakan bahasa yang hampir sama dengan pascal (sering disebut objeck pascal ). Sehingga lebih mudah untuk digunakan . Bahasa pemrograman Delphi dikembangkan oleh CodeGear sebagai divisi pengembangan perangkat lunak milik embarcadero . Divisi tersebut awalnya milik borland, sehingga bahasa ini memiliki versi Borland Delphi .
\end{abstract}

Delphi juga menggunakan konsep yang berorientasi objek ( OOP ), maksudnya pemrograman dengan membantu sebuah aplikasi yang mendekati keadaan dunia yang sesungguhnya . Hal itu bisa dilakukan dengan cara mendesign objek untuk menyelesaikan masalah . OOP ini memiliki beberapa unsur yaitu ; Encapsulation ( pemodelan ), Inheritance ( Penurunan ), Polymorphism ( Polimorfisme ).

Awalnya bahasa pemrograman delphi hanya dapat digunakan di Microsoft Windows, namun saat ini telah dikembangkan sehingga dapat digunakan juga di Linux dan di Microsoft .NET . Dengan menggunakan free pascal yang merupakan proyek OpenSource, bahasa pemrograman ini dapat membuat program di sistem operasi Mac OS X dan Windows CE .

Umumnya delphi hanya digunakan untuk pengembangan aplikasi dekstop, enterprise berbasis database dan program - program kecil . Namun karena pengembangan delphi yang semakin pesat dan bersifat general purpose bahasa pemrograman ini mampu digunakan untuk berbagai jenis pengembangan software. Dan Delphi juga disebut sebagai pelopor perkembangan RadTool ( Rapid Apllication Development ) tahun 1995 . Sehinnga banyak orang yang mulai mengenal dan menyukai bahasa pemrograman yang bersifat VCL ( Visual Component Library ) ini .

Kata Kunci : Penerimaan dan Pengeluaran Kas.

- INTRODUCTION 
Bagaimana sih Struktur bahasa delphi itu? berikut ini adalah kode yang di ambil dari code editor dari contoh Program sederhana, disini belum akan di jelaskan alur program tapi akan di jelaskan struktur Programnya dahulu.

unit Unit1;

interface

uses

Windows, Messages, SysUtils, Variants, Classes, Graphics, Controls, Forms, Dialogs, StdCtrls, ExtCtrls;

type

TForm $1=\operatorname{class}($ TForm $)$

Panel1: TPanel;

Button1: TButton;

procedure Button1Click(Sender: TObject);

private

\{ Private declarations \}

public

\{ Public declarations \}

end;

const pesan='Halo Dunia';

var

Form1: TForm1;

implementation

$\{\$ \mathrm{R} * . \mathrm{dfm}\}$

procedure TForm1.Button1Click(Sender: TObject);

Var s:string;

begin

$\mathrm{s}:=$ pesan;

showmessage('Pesannya adalah ' $+\mathrm{s}$ );

end;

end.

Penjelasanya adalah:

unit Unit1 adalah nama dari unit dari satu object form yang kita pakai, nama ini bisa diganti saat proses penyimpanan Project secara otomatis oleh Aplikasi Delphi. 
Interface Definisi singkat dan mudahnya sebuah interface adalah deklarasi Function, Procedure tanpa implementasi fungsi atau prosedur tersebut, atau bisa di sebut sebagai abstraksi dari program. Jangan bingung yah adek-adek disini secara default sudah di sediakan oleh Bahasa Delphi.

Uses adalah tempat untuk memanggil kumppulan class,function atau procedure buildin yang disediakan system dan library dari luar, jika kita menggunakan komponent standar maka jenis library yang ada di sini secara otomatis akan di isi oleh Applikasi delphi nah adek-adek sangat mudah kan pemrograman visual? banyak sekali hal yang di era pemrograman lama yang disediakan secara otomatis di era pemrograman visual.

Type s/d End adalah deklarasi class utama dari aplikasi kita berisi nama procedure, function dan komponen-komponen yang kita gunakan. Sekali lagi adek-adek bagian ini pun juga sudah di sediakan oleh system jadi akan nambah sendiri ketika kita menambahkan action pada komponen kita, akan kita bahas di pengenalan komponen standar delphi.

const atau dalam bahasa Indonesianya adalah Konstanta adalah suatu penampung data yang bersifat tetap dimana data yang kita definisikan di awal ini nilainya/ datanya TIDAK DAPAT DIRUBAH HANYA BISA DI BACA.

var adalah letak untuk mendevinisikan suatu variable/ Penampung Data/ Penampung nilai sementara dimana jika di definisikan di awal sebuah unit maka akan berlaku global, bisa di baca, di isi di hapus isinya dimanapun dalam sebuah unit.

Procedure adalah implementasi dari interface dimana berisikan tentang kode-kode program yang kita tulis sesuai dengan keinginan kita, kode Program selalu di tulis dan diawali dengan BEGIN dan di akhiri dengan END; pada contoh procedure diatas ada contoh pendekarasian variable Var s:string; Sebelum BEGIN, hal ini menandakan bahwa variable tersebut adalah lokal, jadi hanya bisa diakses pada Procedure event TForm1.Button1Click(Sender: TObject); saja

end. Menandakan akhir dari sebuah unit. secara otomatis setiap unit akan di akhiri oleh statement ini.

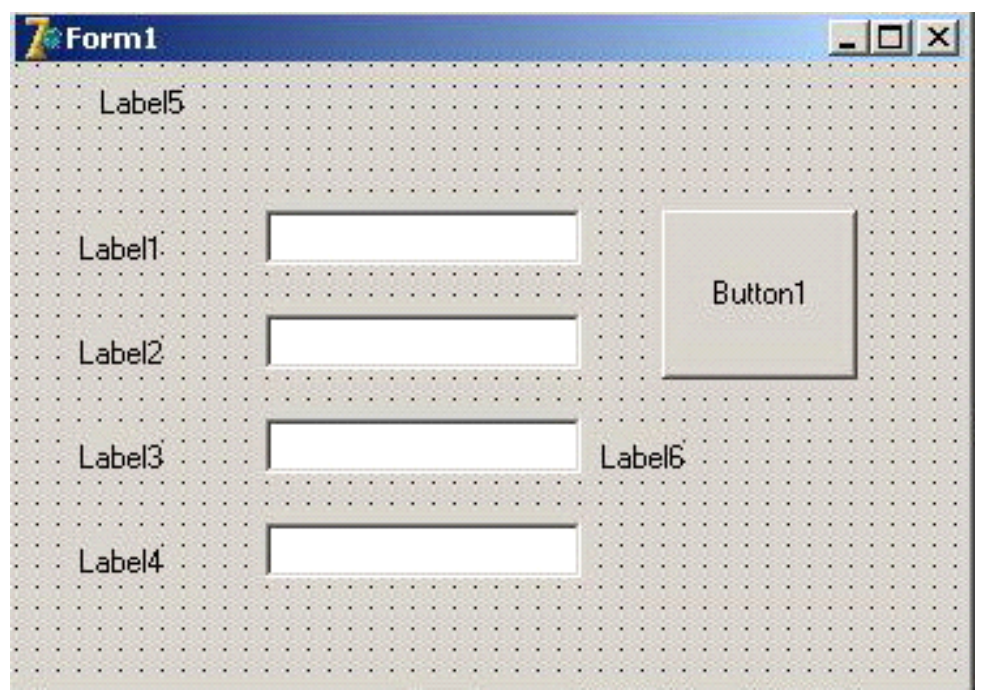




\section{- CONCLUSION}

Kesimpulan

Bahasa pemrograman adalah sebuah instruksi yang di buat oleh manusia untuk menjalankan komputer. Program ini tersusun dari kode-kode yang nantinya kode tersebut akan di terjemahkan oleh komputer itu sendiri.

Di dunia ini banyak sekali jenis bahasa pemrograman yang telah berkembang yang tentunya bisa di manfaatkan dengan baik oleh manusia dalam menjalani kehidupan mereka. Contohnya bahasa pemrograman bisa dijadikan alat untuk belajar, bisa di manfaatkan dalam bidang ekonomi dan masih banyak lagi manfaat yang bisa kita dapatkan dari mempelajari bahasa pemrograman.

\section{- ACKNOWLEDGEMENT}

University Of Mitra Indonesia 
- REFERENCE (Based ISO 690 )

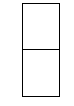

[1] A. S. Putra And O. M. Febriani, "Knowledge Management Online Application In Pdam Lampung Province," In Prosiding International Conference On Information Technology And Business (Icitb), 2018, Pp. 181-187.

[2] A. S. Putra, O. M. Febriani, And B. Bachry, "Implementasi Genetic Fuzzy System Untuk Mengidentifikasi Hasil Curian Kendaraan Bermotor Di Polda Lampung," J. Sist. Inf. Dan Manaj. Basis Data, Vol. 1, No. 1, Pp. 21-30, 2018. 
[3] O. M. Febriani And A. S. Putra, "Sistem Informasi Monitoring Inventori Barang Pada Balai Riset Standardisasi Industri Bandar Lampung," J. Inform., Vol. 13, No. 1, Pp. 90-98, 2014.

[4] Putra, Arie Setya. "2018 Artikel Struktur Data, Audit Dan Jaringan Komputer." (2018).

[5] Putra, A. S. (2018, July 17). Paperplain Fundamental Create Application With Borland Delphi 7.0 University Of Mitra Indonesia. Retrieved From Osf.Io/Pbrn9.

\section{E. REFERENCE (Based APA)}

Putra, A. S., Aryanti, D. R., \& Hartati, I. (2018, November). Metode SAW (Simple Additive Weighting) sebagai Sistem Pendukung Keputusan Guru Berprestasi (Studi Kasus: SMK Global Surya). In Prosiding Seminar Nasional Darmajaya (Vol. 1, No. 1, pp. 85-97).

Sari, D. P., Febriani, O. M., \& Putra, A. S. (2018, November). Perancangan Sistem Informasi SDM Berprestasi pada SD Global Surya. In Prosiding Seminar Nasional Darmajaya (Vol. 1, No. 1, pp. 289-294).

Putra, A. S. (2018). Paperplain: Execution Fundamental Create Application With Borland Delphi 7.0 University Of Mitra Indonesia.

Putra, A. S., Sukri, H., \& Zuhri, K. Sistem Monitoring Realtime Jaringan Irigasi Desa (JIDES) Dengan Konsep Jaringan Sensor Nirkabel. IJEIS (Indonesian Journal of Electronics and Instrumentation Systems), 8(2), 221-232.

Darmawan, A., Yuliawati, D., Marcella, O., \& Firmandala, R. (2016). Sistem Absensi dan Pelaporan Berbasis Fingerprint dan SMS Gateway. EXPLORE, 7(1).

Febriani, O. M., Wahyuni, T., \& Yusuf, S. (2017). DESIGN OF WEBSITE-BASED INFORMATION SYSTEM FOR EDOCUMENT ADMINISTRASI IN THE COMMUNITY SERVICE UNIT (A Case Study at Rajabasa District). INTERNATIONAL JOURNAL OF COMPUTERS \& TECHNOLOGY, 16(7), 7010-7020.

Febriani, O. M., \& Wahyuni, T. (2017, October). PERANCANGAN SISTEM EDOCUMENT ADMINISTRASI LOGBOOK PENELITIAN PADA UNIT LAYANAN DI BANDAR LAMPUNG. In Prosiding Seminar Nasional Darmajaya (Vol. 1, No. 1, pp. 187194).

Febriani, O. M., \& Permadi, A. B. (2017). Implementasi Sistem Aplikasi Data Bimbingan dan Pelanggaran Siswa pada Sekolah Menengah Atas di Lampung Tengah dengan Metode Analisis dan Desain Sistem Terdistribusi (SSAD). EXPERT, 7(1). 
Febriani, O. M., \& Ambarwati, L. (2015). PERANCANGAN APLIKASI PENGOLAHAN DATA PENJUALAN UKM KELANTING KHAS TELO DESA SIDOHARJO KECAMATAN JATI AGUNG KABUPATEN LAMPUNG SELATAN. Jurnal Teknologi Informasi dan Bisnis Pengabdian Masyarakat Darmajaya, 1(1), 77-95.

Febriani, O. M. (2015). Rancang Bangun Aplikasi E-commercemenggunakan Freewebstore pada UKM Kelanting di Desa Sidoharjo Lampung Selatan. Prosiding Sembistek 2014, 1(02), 446-458. 